\title{
NA POGRANICZU JĘZYKÓW, KULTUR I RELIGII: UWAGI 0 TEUMACZENIU DZIENNIKÓW THOMASA MERTONA
}

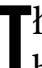
łumaczenie klasyki to rzecz tyleż niełatwa, co nieuchronna. Nieuchronna, bo - jak słusznie zauważa George Steiner - „każde pokolenie ponownie tłumaczy klasykę" (2000: 64), niechybnie z potrzeby przełożenia jej ponadczasowego przesłania na język i mentalność własnych czasów, a niełatwa zarówno $\mathrm{z}$ tego samego powodu (tj. konieczności znalezienia współczesnych wykładników uniwersalnych treści), jak i ze względu na istnienie i oddziaływanie wcześniejszych bądź równoległych przekładów. Z tą klasyczną dychotomią mamy niewątpliwie do czynienia w przypadku tekstów Thomasa Mertona (1915-1968), cystersa-trapisty, mistyka i pustelnika, wymienianego niekiedy jedynym tchem obok św. Augustyna i św. Tomasza z Akwinu. Opinia Józefa Życińskiego, że „znamienne dla Mertona połączenie duchowości, poezji, otwarcia na Bożą transcendencję i na kulturę wielkich wyzwań czyni z jego prac współczesną klasykę" (2003: 8), znajduje potwierdzenie w ich ogromnej międzynarodowej popularności. Polscy czytelnicy doskonale znają Mertona m.in. z autobiografii Siedmiopiętrowa góra, książek Nikt nie jest samotna wyspa i Posiew kontemplacji, W natarciu na niewypowiadalne, Zen 
i ptaki żądzy i Myśli o wschodzie, a także wieloletniej korespondencji z Czesławem Miłoszem (Listy).

Rozpoczynając blisko trzy lata temu pracę nad tłumaczeniem zbioru fragmentów dziennika Thomasa Mertona, miałem tylko częściową świadomość ciężaru zadania, jakiego się podjąłem. Możliwość zdobycia zaszczytnego miana „tłumacza Mertona” i zajęcia miejsca - choćby i na samym skraju bibliotecznej półki - obok m.in. Czesława Miłosza i Elżbiety Tabakowskiej przesłoniła mi z początku trudy i ryzyko tego przedsięwzięcia. Wkrótce jednak miało się okazać, że jest to zadanie zarówno trudne, jak i ryzykowne i oba te aspekty chciałbym pokrótce omówić poniżej.

Pierwsza niełatwa decyzja, przed którą stanąłem, przystępując do tłumaczenia Roku $z$ Thomasem Mertonem, wiązała się z faktem istnienia wcześniejszych przekładów fragmentów jego dzienników na język polski. Należą do nich: Znak Jonasza (tłum. Krystyna Poborska, wyd. Znak 1962, wyd. popr. Zysk i S-ka 2001), Ślub konwersacji (tłum. Aleksander Gomola, wyd. Zysk i S-ka 1997), Dzień obcego (tłum. Marianna Cielecka i Maciej Bielawski, wyd. Homini 2005) oraz Dziennik azjatycki (tłum. Elżbieta Tabakowska, wyd. Znak 1993). Notabene tłumaczka ostatniej wymienionej pozycji przywołuje w innym miejscu znaną zasadę głoszącą, że „teksty które już ktoś przed nami przetłumaczył (w domyśle: i wydał) należy cytować w przekładzie tego kogoś” (Tabakowska 1999: 115), choć jednocześnie opisuje przypadki własnych licznych odstępstw od tej zasady. Zachęcony tym przykładem postanowiłem ostatecznie - wbrew dobrej praktyce translatorskiej - nie sięgać do wcześniejszych tłumaczeń Dzienników. Zdecydowały o tym trzy powody. Po pierwsze każdy $\mathrm{z}$ istniejących polskich przekładów dotyczył fragmentów pochodzących ze stosunkowo krótkich okresów życia Mertona, natomiast tłumaczony przeze mnie zbiór obejmował zapiski powstałe na przestrzeni ponad dwudziestu lat. Zważywszy na specyficzną formę książki, której podtytuł brzmi Codzienne medytacje, uznałem, że skoro tworzy ona pewną całość - niezależnie od arbitralnej kompozycji zbioru dokonanej przez redaktora angielskiego oryginału - spójność stylistyczna będzie korzystniejsza niż eklektyzm wywołany wzbogacaniem swojego przekładu pracą pięciorga innych tłumaczy, na podobieństwo placka przetykanego rodzynkami. Po drugie pomiędzy poszczególnymi wydaniami dzienników Mertona istnieją poważne rozbieżności, spowodowane $\mathrm{w}$ znacznej mierze tym, że zgodnie $\mathrm{z}$ testamentem pisarza jego prywatne pisma i korespondencja mogły zostać wydane nie wcześniej niż 25 lat po jego śmierci (Person 2003: 81) - a tym samym kompilacje Dzienników sprzed roku 1993 są z konieczności niepełne. Obrazuje to dobrze przykład Znaku Jonasza, który w przekładzie Krystyny Poborskiej ukazał 
się po raz pierwszy w roku 1962, natomiast wznowienie z roku 2001 zawiera fragmenty nieujęte w pierwszym wydaniu, przetłumaczone przez Marka Maciołka. Po trzecie wreszcie pod wpływem lektury Dzienników doszedłem do wniosku, że ich język cechuje swoista prostota i surowość, co powinno znaleźć odzwierciedlenie w nowym przekładzie. Wnioski te potwierdziły późnej opinie znawców twórczości Mertona, z których jeden tak komentował decyzje komisji redakcyjnej wznowienia innego znanego dzieła:

Jednak język nowego przekładu znacząco różni się od dawnego. Dawne przekłady tego autora niejednokrotnie poczytywały sobie za obowiązek stylizowanie go na język dwunastowiecznych traktatów monastyczno-duchowych, na język, którym de facto Merton nigdy nie mówił i nie pisał (jeśli już mu się to zdarzyło, to bardzo tego żałował i bardzo się wstydził). Dzisiaj, nawet na polskim rynku czytelniczym, obraz tego autora jest znacznie bardziej odbrązowiony - trzeba dodać, że z wielką korzyścią dla recepcji jego duchowości. (Bielawski 1999: 287)

W tego rodzaju obserwacjach i podjętych na ich podstawie decyzjach wsparli mnie nie tylko krytycy, ale również inni tłumacze. Ewa E. Nowakowska we wstępie do swojego przekładu W natarciu na niewypowiadalne pisze:

Merton jakby umyślnie unika w wielu momentach synonimów, popisowych chwytów, cacek językowych, opowiadając się po stronie powtórzeń (jakże typowych dla „Biblii” i wszelkiej literatury archaicznej), które bardzo uderzają przy lekturze oryginału i mogą w polskim przekładzie sprawiać wrażenie, że tłumaczka wcale nie zna wyrazów bliskoznacznych, a jej styl brzmi kulawo. Tłumaczka zatem pragnie zauważyć, że celowo powtarza ten sam wyraz lub frazę w wielu zdaniach, bo tak właśnie zadecydował Merton. Być może chciał przez to powiedzieć: kiedy używam słowa „ogień”, „prawda”, „niebo”, to mam na myśli te zjawiska, a nie, na przykład, „ogniki”, „oczywistości”, „błękit”, etc. (1997: 10)

Wymieniwszy najważniejsze powody, by pomimo niewątpliwego ryzyka oprzeć się wyłącznie na własnej pracy i nie korzystać z wcześniejszych przekładów, przejdę teraz do omówienia trzech najważniejszych wymiarów stanowiących o specyfice Dzienników Mertona - a także typowych dla nich wyzwań przekładowych - powstających odpowiednio na styku języków, kultur i religii.

Zacznijmy od pogranicza języków. Thomas Merton urodził się we Francji jako syn Nowozelandczyka i Amerykanki, a zanim w wieku 26 lat wstąpił do klasztoru trapistów w Gethsemani w Kentucky wychowywał się i kształcił 
kolejno w Ameryce, Francji, Anglii i ponownie w Ameryce. Jego praktyczną dwujęzyczność uzupełniała naturalnie znajomość łaciny i greki, a w kolekcji książek, którą pozostawił po sobie na Uniwersytecie św. Bonawentury bezpośrednio przed rozpoczęciem życia zakonnego, znaleźć można również liczne pozycje po hiszpańsku, niemiecku i włosku ${ }^{1}$. Nic dziwnego, że na kartach jego dzienników pojawiają się niekiedy wyrażenia lub całe zdania w każdym spośród sześciu wspomnianych języków. $Z$ punktu widzenia tłumacza nie stanowi to wielkiej trudności, z reguły bowiem wtrącenia obcojęzyczne pozostawia się $\mathrm{w}$ brzmieniu oryginalnym, a w razie potrzeby wyjaśnienie istotnych terminów można zawrzeć $\mathrm{w}$ przypisach. Oczywiście zawsze rodzą się pytania o zakres lingwistyczno-encyklopedycznej wiedzy przeciętnego czytelnika, których nie sposób rozstrzygnąć systemowo, więc ostatecznie liczba i charakter przypisów odzwierciedla subiektywne oceny tłumacza (a na dalszym etapie - redaktora), który w tym przypadku Codziennych medytacji uznał za stosowne objaśnić pokrótce znaczenie i konotacje terminu aggiornamento, a jednocześnie postanowił nie komentować tak istotnych pojęć, jak kairos czy Gelassenheit. Bez komentarza pozostały również liczne wtrącenia i nawiązania łacińskie - dość chyba oczywisty element zapisków rzymskokatolickiego zakonnika z czasów w większości poprzedzających Vaticanum Secundum.

Wśród stosunkowo nietrudnych decyzji translatorskich związanych z wielojęzycznością Dzienników zdarzały się jednak również kwestie problematyczne, jak chociażby sprawa pisowni nazw i wyrażeń pochodzących z języków pozaeuropejskich. Fascynacja Mertona kulturą i religiami Wschodu znajduje wyraz m.in. w licznych odwołaniach do klasycznych tekstów spisanych $\mathrm{w}$ sanskrycie oraz do wywodzących się $\mathrm{z}$ nich pojęć. Autor stosuje transkrypcję fonetyczną, nie zawsze odpowiadającą formie przyjętej $\mathrm{w}$ anglojęzycznych encyklopediach i opracowaniach naukowych, co w przekładzie nastręcza trochę trudności decyzyjnych, ponieważ polskie źródła leksykograficzne dopuszczają często oboczności zapisu (np. adwajta lub adwaita) ${ }^{2}$. Problem ten jednak w nieporównanie większym stopniu dotyczy Dziennika azjatyckiego, który zasłużył nawet na osobną redakcję przypisów, krótki przewodnik fonetyczny, słownik terminów i pojęć oraz posłowie redaktora wszystkich tych materiałów, który pisze:

${ }^{1}$ Por. Books Left at St. Bonaventure When Merton Entered Religious Life, http://web.sbu.edu/ friedsam/archives/mertonweb/usedbymerton.htm.

2 Słownik języka polskiego PWN (http://sjp.pwn.pl). 
Osobną sprawą jest kwestia licznie występujących w tekście Dziennika słów orientalnych - terminów i imion własnych pochodzących z języków takich jak sanskryt, pali i tybetański. Z uwagi na charakter Dziennika, będącego zapisem impresji, ale również [...] tekstem poniekąd źródłowym, przyjąłem zasadę oddawania tych słów dwojako: w tekście figurują one w postaci spolszczonej, oddającej w przybliżeniu ich brzmienie, w przypisach zaś podaję je w naukowej transkrypcji międzynarodowej. (Kania 1993: 283)

Pocieszam się, że w przypadku Codziennych medytacji tak wysoki stopień precyzji zapisu nie był zapewne konieczny, co oczywiście nie usprawiedliwia wielu niekonsekwencji fonetyczno-ortograficznych, jakie z dzisiejszej perspektywy dostrzegam w swoim przekładzie. Wyjaśnić je natomiast można tym, że podczas kilkumiesięcznej pracy nad tłumaczeniem stosunkowo obszernej książki, ocena tych samych zagadnień i sposób podejścia do nich z reguły się zmienia w miarę jak tłumacz zdobywa lepszą orientację w danej tematyce lub po prostu z czasem odkrywa lepsze rozwiązania trudności przekładowych. W Codziennych medytacjach widać to dobrze na przykładzie odwołań do chińskiego filozofa i poety 莊子. Merton wspomina go czterokrotnie, stosując konsekwentnie transkrypcję typową dla angielszczyzny (Chuang Tzu). Tłumacz był wprawdzie świadom konieczności dopasowania zapisu do polskiej konwencji fonetycznej, ale świadomość ta krystalizowała się dwuetapowo: za pierwszym razem bowiem ograniczył swoją interwencję do drugiego członu, pisząc Chuang $C y$, a dopiero w drugiej i kolejnych wzmiankach napisał $C z u a n g C y$, jak nakazuje polska ortografia, zgodnie z którą afrykatę $[t s]$ zapisuje się jako $c$ (a nie $t z$, jak po angielsku, o czym tłumacz cały czas pamiętał), a [t]] jako $c z$ (a nie $c h$, jak po angielsku, o czym tłumacz za pierwszym razem zapomniał). W tym miejscu jako ciekawostkę można podać, że trzy polskie encyklopedie wymieniają łącznie aż 11 sposobów zapisu tego imienia: Zhuangzi, Zhuang Zhou, Zhuangzhou, Chuang Chou, Chuang Tzu, Chuang Tsu, Chuang Tse, Chuang-tse, Czuang-tsy, Czuang-cy i Czuang Czou, natomiast wydawca polskiego przekładu innej książki Mertona pt. Droga Chuang Tzu postanowił trzymać się transkrypcji angielskiej (również dopuszczonej przez niektórych leksykografów).

Obecność w Dziennikach wielu języków świadczy bezpośrednio o tym, że ich autor żył i funkcjonował na pograniczu wielu kultur. Dnia 10 lipca 1964 r. zanotował: „Literatura, kontemplacja, samotność, Ameryka Łacińska, Azja, zen, islam, itd. Wszystkie te rzeczy łączą się w moim życiu”. Rzeczywiście niemal na każdej stronie Dzienników przeplatają się odwołania do kultury Wschodu i Zachodu, czasów minionych i współczesnych. William Blake sąsiaduje z Laozim, Rainer Maria Rilke z Grzegorzem z Nyssy, Flannery O’Connor z Julianną z Norwich, a Czuang Cy z Borysem Pasternakiem i Czesławem 
Miłoszem. Ponieważ jednak zakorzenienie w wielu erach i kulturach jednocześnie cechuje niejednego autora o ambicjach kosmopolitycznych - choćby wspomnianego na początku George'a Steinera - a związane z tym problemy przekładowe są stosunkowo oczywiste (podobnie jak oczywiste jest ich rozwiązanie: tłumacz powinien być po prostu niedościgłym erudytą), chciałbym się raczej skupić na tym, co stanowi o wyjątkowości Dzienników Mertona, zawężając zakres dalszych obserwacji do sfery religijnej.

Podstawową trudność - nie tylko dla tłumacza, ale dla czytelnika - związaną z tym wymiarem Dzienników przewiduje sam autor, pisząc we wstępie do Znaku Jonasza:

Nie przypuszczałem ani przez chwilę, że książka ta, która jest zbiorem osobistych notatek i rozważań spisywanych w ciągu pięciu lat mojego pobytu klasztorze Gethsemani, będzie czytana przez ludzi nieobznajomionych z życiem klasztornym. Dlatego pisząc nie starałem się wyjaśniać zwyczajów i stałych praktyk powszedniego dnia trapistów i nie uważałem za konieczne podmalowywać tło. Stąd „Dziennik” byłby miejscami niezrozumiały, gdyby czytelnik nie miał w pamięci choć szkicowego obrazu klasztoru i życia w naszym zgromadzeniu. (Merton 1962:5)

Rzeczywiście - aby polska wersja Codziennych medytacji nie była miejscami jeszcze bardziej niezrozumiała, niż mógłby sądzić autor, tłumacz musiał poświęcić niemało czasu na zapoznanie się z tematyką monastyczną, co wymagało wczytania się w historię zakonu trapistów (a przy tym również cystersów i benedyktynów, z których się wywodzą) oraz poznania ich reguły, struktury i praktyk, by na przykład nie pomylić opata z przeorem, a nieszporów z kompletą. Wzmianki o Małym Kwiatuszku czy Doktorze Anielskim kazały tłumaczowi uzupełnić wiedzę na temat rzymskokatolickiej teologii dogmatycznej, która dopiero pozwoliła je powiązać odpowiednio ze św. Teresą z Lisieux i św. Tomaszem z Akwinu. Dla tłumacza obeznanego wprawdzie z materią doktrynalną katolicyzmu, ale wychowanego w innej tradycji wyznaniowej, były to zadania zarazem ciekawe i wymagające.

O tym, że odmienne pochodzenie konfesyjne nie musi koniecznie utrudniać przekładu dzieła religijnego, dane było tłumaczowi przekonać się w konfrontacji z biblijną intertekstualnością Dzienników. Merton nawiązuje do Pisma Świętego często i na rozmaite sposoby, zazwyczaj jednak nie w formie bezpośrednich cytatów, lecz raczej aluzji i obrazów. Oto typowy przykład:

Sednem wszelkiego życia duchowego jest Chrystus we mszy - nasz Baranek Paschalny, który został zabity i ,już więcej nie umiera”, ale „przyciąga 
wszystkich do siebie”, abyśmy - ochrzczeni w Jego śmierci, krzyżując własne ciało wraz jego pożądaniami - mogli żyć Jego życiem, ukryci z Chrystusem w Bogu. (Merton 2006: 110)

Przekładając ten fragment, w którym tylko dwa cytaty zostały wyróżnione cudzysłowem - a i wówczas bez wskazania źródła - tłumacz błogosławił wyniesiony z młodych lat etos codziennej lektury Biblii, który pomógł mu zauważyć cztery kolejne nawiązania do nowotestamentowych fragmentów, a następnie za pomocą konkordancji zlokalizować je w przypisach jako Rz 6,3-9; J 12,32; Ga 5,24 i Kol 3,3. Wprawdzie w ogólnej dyskusji nad rolą, zakresem i sensem przypisów od tłumacza pojawiają się odmienne opinie, jednakże w przypadku Codziennych medytacji da się chyba obronić tezę, że podkreślenie silniejszego zakorzenienia zapisków Mertona w Piśmie Świętym, niż w pierwszej chwili mogłoby się wydawać, pomogło nieco złagodzić obawy autora wyrażone w przywołanym wcześniej fragmencie wstępu. Między innymi za sprawą przypisów czytelnik uzyskuje bowiem „choć szkicowy obraz” mniej widocznych biblijnych korzeni, dzięki którym - a nie mimo których! - Thomas Merton wniósł tak ogromny wkład w rozwój dialogu ekumenicznego. W tym kontekście mediacyjna rola tłumacza nabiera szczególnego znaczenia.

Jednocześnie dla równowagi warto przypomnieć, że wyczulenie - w tym przypadku na nawiązania biblijne - od przeczulenia dzieli dość wąska granica, którą nie zawsze potrafiłem należycie ocenić. Dobrze ilustruje to przykład zdania „I always overshadowed Jonas with my mercy” (Merton 2006: 218), wypowiadanego przez samego Boga, które - pod wpływem jednego z wątków przywoływanej tu biblijnej narracji, w której Jonasz rozpacza nad losem uschniętego krzewu rycynowego, imputując Bogu brak miłosierdzia ${ }^{3}$ - mylnie zinterpretowałem jako „zawsze przewyższałem Jonasza swoim miłosierdziem", gdy tymczasem rację ma Krystyna Poborska, tłumacząc je po prostu jako „osłaniałem zawsze Jonasza swoim miłosierdziem” (Merton 1962: 334). Wprawdzie czasownik overshadow może wyrażać oba wspominane znaczenia, ale drugie $z$ nich znacznie lepiej harmonizuje $z$ wymową kontekstu. Jak powiedzieliśmy na początku, tłumaczenie klasyki zawsze obejmuje element ryzyka, w tym również porównania z cudzym przekładem, który niekiedy może okazać się trafniejszy. Ot, kolejna lekcja translatorskiej pokory, której nigdy za wiele.

Podobne obserwacje przekładowe można by oczywiście mnożyć - ale nie w tym rzecz, skoro „tłumaczom, którzy piszą o swojej pracy, zawsze grozi nie-

\footnotetext{
${ }^{3}$ Por. Jon 4, 1-11.
} 
bezpieczeństwo, że w efekcie ich trudu powstaną po prostu mniej lub bardziej szczegółowe rejestry konkretnych przykładów szczegółowych rozwiązań pojedynczych problemów" (Tabakowska 1999: 87). Czas zatem na podsumowanie przedstawionych dotychczas uwag. Zawrę je $\mathrm{w}$ jednym zdaniu: niezależnie od rozmaitych wyzwań, trudności i ryzykownych posunięć typowych dla pogranicza języków, kultur i religii - a może właśnie dzięki wszystkim tym rzeczom - tłumaczenie dzienników Mertona pozwoliło mi wielokrotnie i obficie zakosztować tego, co w pracy tłumacza pociąga mnie chyba najbardziej: metafizyki mediacji między myślą autora (choć nie zawsze w pełni dostępną i zrozumiałą) a światem czytelnika (choć nie zawsze znanym bądź określonym). Nie jest to zapewne refleksja nowa, ale i w tym względzie solidaryzuję się z wnioskami Thomasa Mertona:

Prowadzenie dziennika nauczyło mnie, że życie wewnętrzne nie jest aż tak bogate, jak się czasem wydaje. Czytając własny dziennik, dochodzi się do wniosku, że najnowszego odkrycia już raz dokonaliśmy przed pięciu laty. Po prostu zagłębiamy się coraz bardziej w te same idee i doświadczenia. (2006: 228)

\section{Literatura}

Bielawski, K., 1999, Posłowie od redakcji wydania polskiego Nowego posiewu kontemplacji, Kraków, s. 285-287.

Kania, I., 1993, „Od redaktora przypisów”, [w:] Merton, T., Dziennik azjatyc$k i$, tłum. E. Tabakowska, Kraków.

Merton, T., 1962, Znak Jonasza, tłum. K. Poborska, Kraków.

Merton, T., 2006, Rok $z$ Thomasem Mertonem. Codzienne medytacje, tłum. P. Blumczyński, Kraków.

Nowakowska, E. 1997, „Od tłumaczki”, [w:] Merton, T., W natarciu na niewypowiadalne, Bydgoszcz, s. 9-11.

Person, P.M., 2003, „Thomas Merton - archiwista”, tłum. A. Muranty, [w:] Studia Mertoniana, 2, Bielawski, K. (red.), Kraków, s. 65-85.

Steiner, G., 2000, Po wieży Babel. Aspekty języka i przekładu, tłum. W.O. Kubińscy, Kraków.

Tabakowska, E., 1999, O przekładzie na przykładzie, Kraków.

Życiński, J., 2003, „Merton a ekologia ludzkiego ducha”, [w:] Studia Mertoniana, 2, Bielawski, K. (red.), Kraków, s. 7-9. 
Between languages, cultures, and religions: some comments on translating Thomas Merton's journals into Polish

\section{Summary}

The fact that translating classics is both difficult and inevitable is exemplified in the copious translations of Thomas Merton's works worldwide. In the Polish context, the challenge of translating Merton is additionally amplified by the existence of translations produced by prominent writers and scholars (e.g. Miłosz, Tabakowska). In the article, the translator of $A$ year with Thomas Merton. Daily meditations from His Journals provides an overview of peculiar difficulties encountered while working on the Polish version. In particular, he focuses on the influence of the earlier Polish translations of parts of the Journals as well as Merton's distinctive style (often manifested in excessive repetitiveness and lexical simplicity paired with the richness of thought). However, most translational challenges seem to have arisen in relation to Merton's command and abundant use of multiple languages, his fascination by various cultures, and rootedness in the Christian - particularly Roman Catholic - heritage and the monastic tradition. The discussion of the actual translational challenges is accompanied by personal comments of the translator. 